\title{
Performance Study of a Solar Still with a Solar Preheating of Brackish Water
}

\author{
Kabi Abdennacer ${ }^{1}$ and Halloufi Oualid ${ }^{1}$
}

\begin{abstract}
The lack of drinking water represents actually a major problem as its demand is going increasingly all over the world. Solar desalination process represents, in the immediate and or in the future term an alternative solution, especially for the areas where the water shortage is present. The use of desalination through a solar still is appropriate as far as it needs less high technology and is characterized by its more or less low cost and where the used energy (solar energy) is free and clean. The aim of this study is to improve the solar desalination by coupling a solar still with a solar collector from which the brackish water is preheated prior to its desalination as well as to study its effect on the performance (efficiency) system. This study is carried out according to geographical and climatologic data collected from the area of Constantine (north east of Algeria).

The results issued from this study show the importance of the internal and the external parameters such as wind velocity, external temperature, collector inclination, brine thickness and thermodynamic factors on the system performance. The considered results show also that the coupling system has an important impact on respectively the production improvement, the efficiency system and the performance factor.
\end{abstract}

Keywords - solar still, solar collector, performance, efficiency..

\section{INTRODUCTION}

$\mathrm{W}$ ATER is essential for life but its availability is not insured all over the world. However, water reserves (water resources) are important, where they are estimated over one billion $\mathrm{km} 3$ compared to the actual world consumption which is less than $1.500 \mathrm{~km} 3$ / year. The major part of these reserves $(97 \%)$ is saline or brackish while the remaining (70 $\%)$ is mainly consisted of ice. Finally, we can estimate the available water fraction, really available, around $7.500 \mathrm{~km} 3$. The desalination market is being in a full progress $(7 \% /$ year).

Solar still production (performance) depends on the temperature gradient which exists between the water temperature in the basin and the temperature issued from the transparent cover and where many studies are carried out in this case [1-5]. Many techniques are tested in order to increase water temperature in the basin as well as to lower that issued from the transparent cover.

To do so, we propose a solar still having a solar preheating system (solar collector) and then compare its performance with a similar system but without any preheating means. We then

\footnotetext{
${ }^{1}$ Climatic Engineering Department, University of Mentouri, Constantine, Algeria
}

study the effect of the considered coupling on the solar still performance (simple and flat solar still).

\section{PROCEDURE FOR PAPER SUBMISSION}

The performance parameters of the considered solar collector are:

- External parameters such as radiation, ambient (external) temperature and wind velocity.

- Internal parameters such as inclination and direction of the collector, collector size and cross section inside which the fluid is flowing

\section{MODEL DESCRIPTION}

The considered model consists of a simple glazed collector coupled with a simple and flat solar still (figure 1). For a simplification purpose, we consider that heat losses between the collector and the solar still are negligible and the temperature at the collector outlet is equal to that at the solar still inlet.

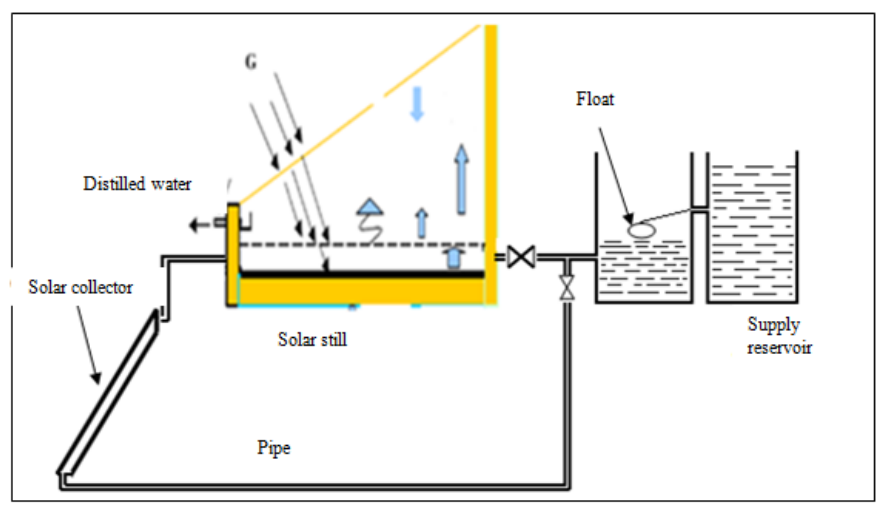

Fig.1: Solar still with a preheating system

\section{INTERPRETATION AND DISCUSSION OF THE RESULTS}

Computations are set up in the area of Constantine (north east of Algeria), in which the geographical coordinates are: latitude of $37^{\circ} 17^{\prime}$ to the north, longitude of $6^{\circ} 62^{\prime}$ to the east and a time difference of one hour. Simulation is carried out, for each solar still component, from an initial instant " $\mathrm{t}_{0}$ " and at an initial temperature " $\mathrm{T}_{0}$ " and with a step time of one hour. July $17^{\text {th }}$ is selected as a calculation day (representative day of the month).

The study is carried out on a flat solar still with a basin absorber of an area, $A_{b}=1 \mathrm{~m}^{2}$ and a thickness, $\delta_{b}=4 \mathrm{~mm}$, a brackish water thickness, $\delta_{\mathrm{e}}=2 \mathrm{~cm}$, a glass area, $\mathrm{A}_{\mathrm{v}}=5 \mathrm{~m}^{2}$ and an insulator with a thickness, $\delta_{\text {iso }}=5 \mathrm{~cm}$ and an area, $\mathrm{A}_{\text {iso }}=$ 
$1.5 \mathrm{~cm}^{2}$. The considered solar still has an inclination angle of $30^{\circ}$ and directed to the south.

In the case of a preheating system, we use a thermal solar collector connected to a fluid pipe where in which there is a mean velocity of $0.08 \mathrm{~m} / \mathrm{s}$. The wind velocity is considered constant and equals to $4 \mathrm{~m} / \mathrm{s}$.

The effect of the temperature difference "brine-glass" on the production is illustrated through the figure 2 , where the considered production increases as the temperature difference between the water layer (brine) and the internal glass area increases. Similar results are found in an experimental study where the production increases with the increase of $T_{e}-T_{v i}$ is observed [3].

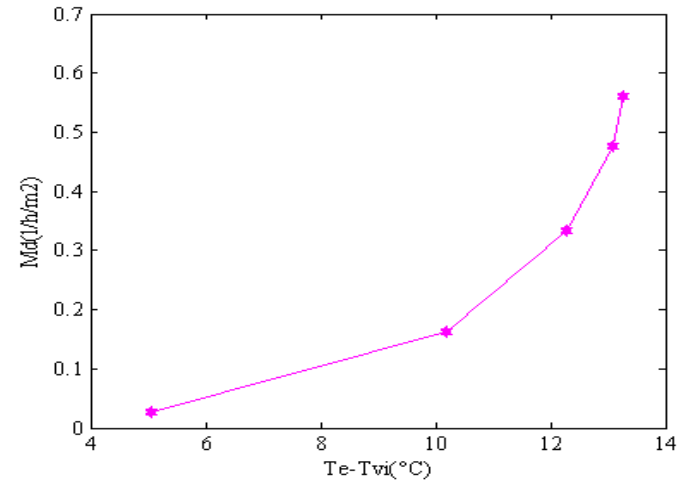

Fig. 2: Production change with temperature difference "brine-glass".

It is noticed that the distiller production increases with the increase of the brine temperature (Te) (figure 3). However, this increase slows down for higher temperatures. This result agrees with certain experimental results [6].

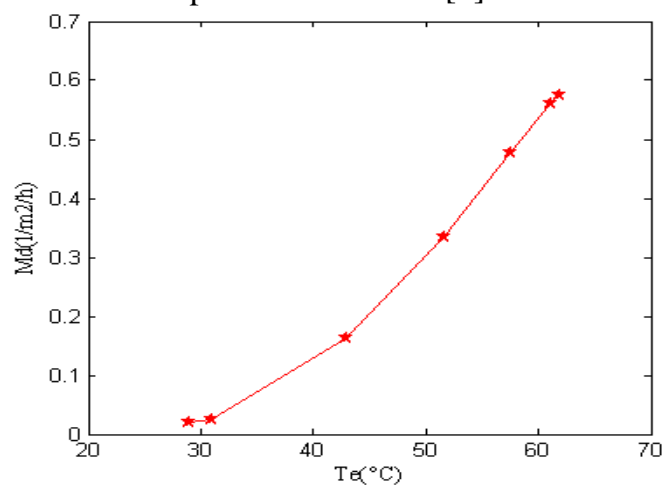

Fig. 3: Production change with the brine temperature

Figure 4 shows that the fluid temperature at the outlet (contributed temperature) increases with time till reaching a maximum value of $72{ }^{\circ} \mathrm{C}$ then it starts its decrease for the rest of the day. As the considered temperature is higher than that being in the solar still, we can, therefore, say that the used collector is sufficient for solar preheating of saline (brackish) water.

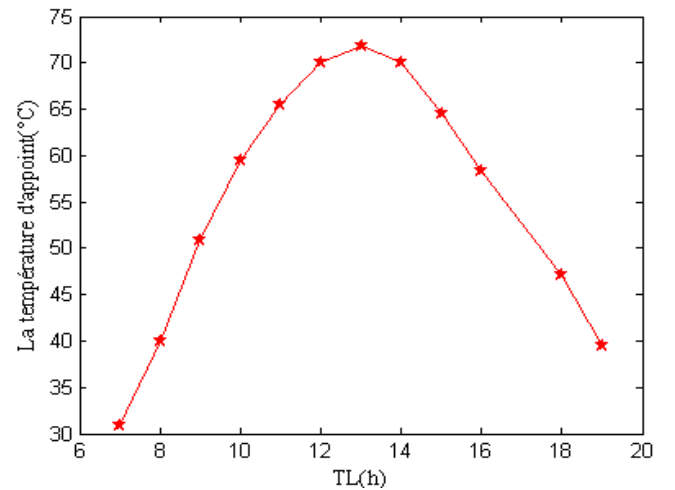

Fig. 4: Temporal changes of the contributed temperature

We can observe through figure 5 that temperatures change of each solar still component seems similar to that issued from a non preheating system excepting that the temperature values are higher. This can be explained by the preheating of the temperature which leads to a preheating of the internal side of respectively the insulator, the basin, the brine and the internal side of the glass. Some experimental works lead to similar results $[2,5]$.

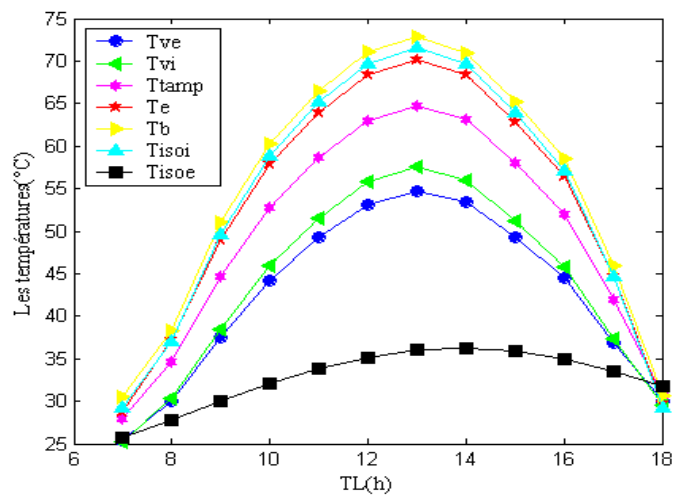

Fig. 5: Temperature changes at different components of a solar still with a preheating system

Figure 6 shows the temporal change of the brine temperature for both a preheating and a non preheating system. The obtained maximum values are $70.14{ }^{\circ} \mathrm{C}$ for the first one and $61.84{ }^{\circ} \mathrm{C}$ for the second one. These results agree with an experimental work carried out by Menina et al. [2].

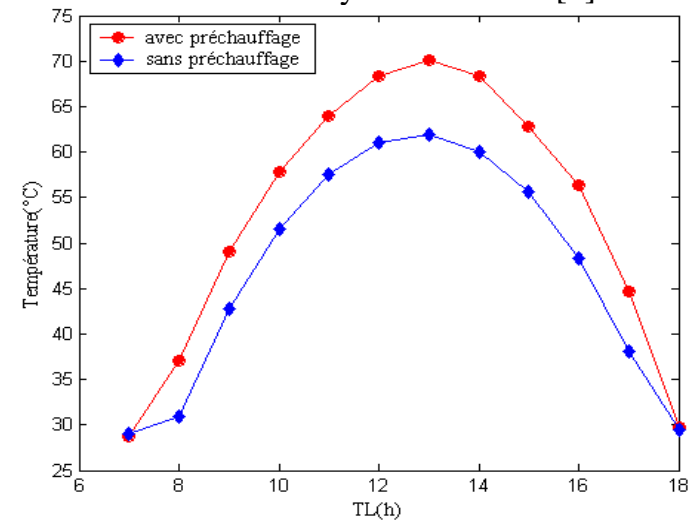

Fig. 6: Temporal changes of water temperatures with and without a preheating system

The hourly production in both systems (figure 7) is almost nil, during the first hours of the day (before 8.00 hours), where the system must reach its working temperature. From the 
indicated moment, it first appears a difference, in terms of production, between the solar still and the coupling system (solar still + solar collector) and where the hourly production starts to increase, reaching the maximum value at 13.00 hours and where the hourly production of the solar still is 0.57 $1 / \mathrm{m}^{2} / \mathrm{h}$, while that issued from the coupling system reaches 0.86 $1 / \mathrm{m}^{2} / \mathrm{h}$. Later, this difference decreases with the solar time, which explains that the preheating water through the solar collector increases the temperature difference between the water and the internal glass of the solar still. This has a direct effect on the increase in the evaporation rate, leading to an improvement on the total production of the distilled water. The temporal changes of the production, for both systems, have the same appearance compared with results issued from an experimental study carried out by Badran et al. [5], where they found an increase on the production of $36 \%$ when a coupling system is used.

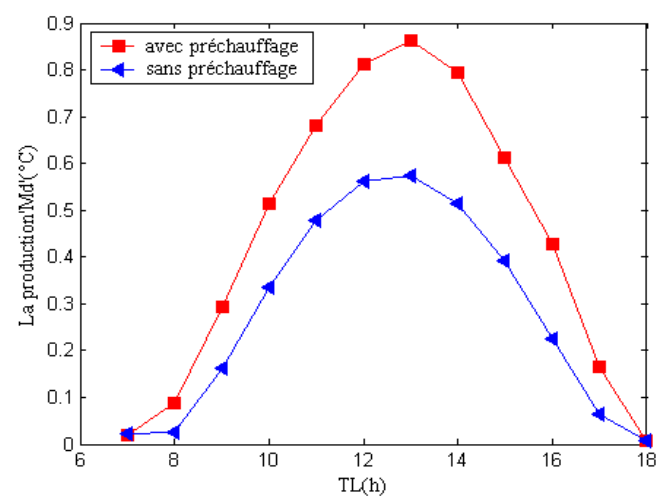

Fig. 7: Temporal changes of the production for a solar still with and without a preheating system

Figure 8 shows that the production increases progressively with the preheating temperature. In fact, this increase in temperature leads to warm up water inside the basin (evaporation surface), resulting to a condensation increase. These results agree with those obtained by Z. Haddad et al. [1] where they observed that the production increases progressively with the preheating temperature and where the production starts to decrease beyond a temperature value of 85 ${ }^{\circ} \mathrm{C}$.

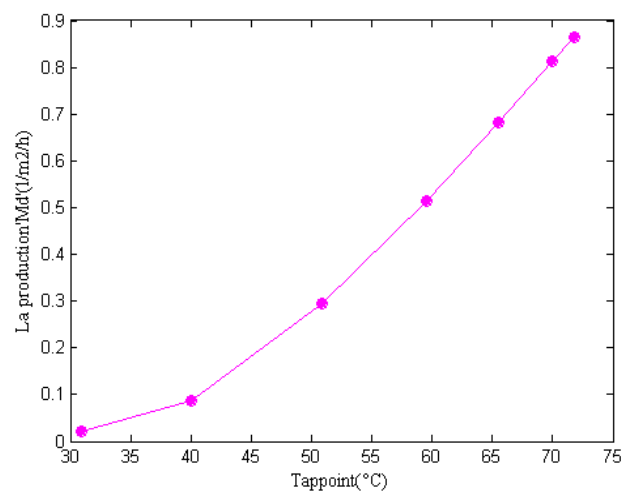

The temporal change of the global efficiency (figure 9) is similar to that issued from the global radiation. At the beginning, there is an increase in the global efficiency reaching its maximum value at 13.00 hours then it decreases for the rest of the day. It is noticed that the global efficiency, in the case of a system without a preheating temperature, is about $37 \%$ whereas in the case of a preheating system, it can reach $56 \%$. These results agree well with some experimental works [1].

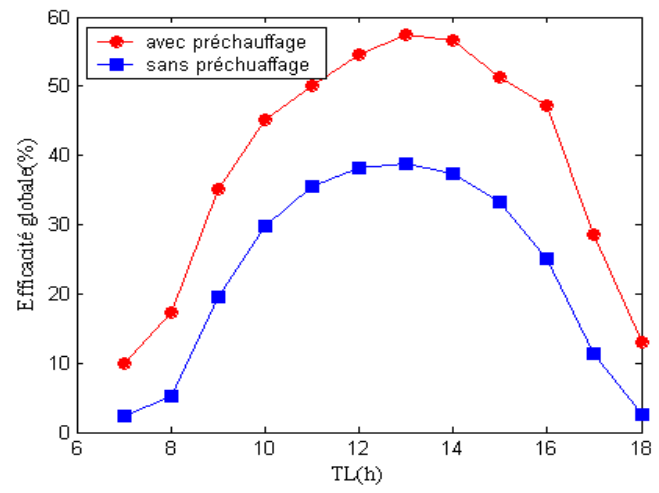

Fig. 9: Temporal changes of the global efficiency for a solar still with and without preheating system

Figure 10 shows the temporal changes of internal efficiency for both systems, where we can observe through the obtained results that maximum values of 0.89 and 0.72 are obtained for successively solar stills with and without a preheating system.

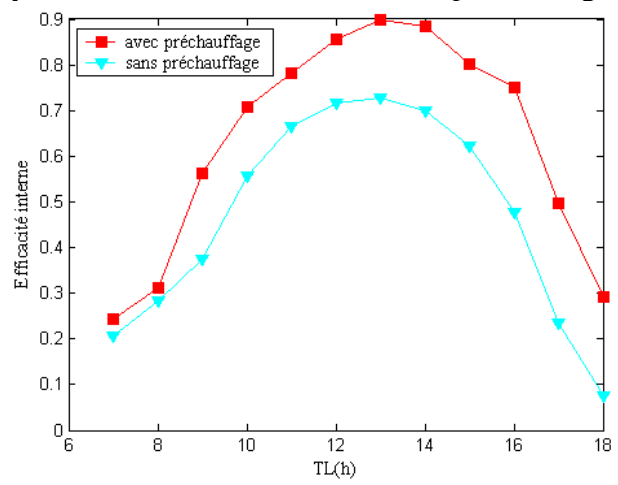

Fig. 10: Temporal changes of the internal efficiency for a flat solar still with and without a preheating system.

Figure 11 shows the performance factor increasing with time, for both systems till reaching a maximum value at 13.00 hours, and then there is a decrease of the considered factor for the remaining time of the day. We can also observe that the performance factor, in the case of a preheating system, is largely higher than that without a preheating system

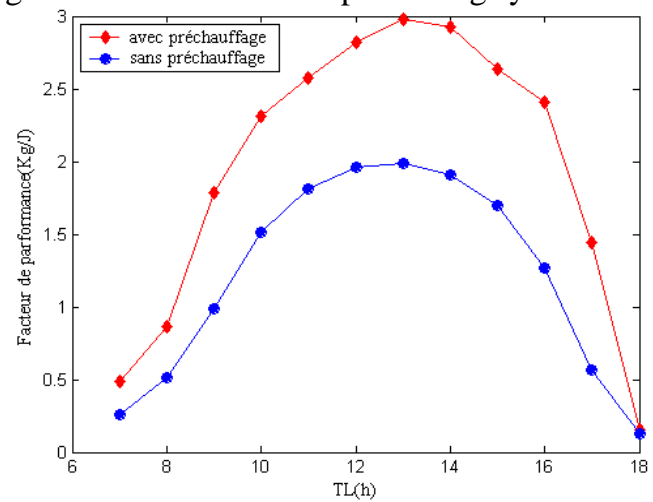

Fig. 11: Change of the performance factor for a flat solar still with and without a preheating system. 


\section{V.CONCLUSION}

The present work concerns a theoretical and a numerical study of the performance of a flat solar still with a preheating of the brine (brackish water) prior to its distillation. This study is carried out according to geographical and climatologic related to the area of Constantine (north east of Algeria).

The obtained results highlight the effect of the internal and external parameters on the performance characteristics of the solar still such as: the production, the internal and global efficiencies and the performance factor. It is noticed that thermophysical parameters of the brine affect much more the production as they depend on the brine temperatures which, themselves, are affected by the radiation parameters as well as by the ambience.

We observe then, that the use of a preheating system (solar collector) leads to an increase of the temperature difference between the evaporation surface and the condensation one, allowing the improvement of respectively the production, the efficiency and the performance factor of the considered system.

\section{REFERENCES}

[1] Z. Haddad, A. Chaker \& N. Boukerzaza, Etude du couplage d'un distillateur solaire avec un capteur plan, Revue des Energies Renouvelables ICRESD-07, Tlemcen, 2007, pp. 179 - 186.

[2] R. Menina, H. Ben Moussa, L. Zemmouri \& A. Moussaoui, Etude expérimentale de l'effet du préchauffage sur la productivité d'un distillateur solaire type : Hot - BoxRev, Energ. Ren., Journées de Thermique, 2001, pp. 145-150.

[3] K. Voropoulos, E. Mathioulakis \& V. Belessiotis, Experimental investigation of a solar still coupled with solar collectors, European Conference on Desalination and the Environment: Water Shortage, Lemesos, Cyprus, 28-31 May 2001. http://dx.doi.org/10.1016/s0011-9164(01)00251-x

[4] M. Boukar \& A. Harmim, Production nocturne d'un distillateur solaire couplé à un capteur Plan en Milieu Saharien, Rev. Energ. Ren. : Valorisation, 1999, pp. 91-96

[5] O.O. Bardan \& H.A. AL- Tahaineh, The Effect of Coupling a flat-plate collector on the solar still productivity, Conference on Desalination and the Environment, Santa Mergherita, Italy, 22-26 May 2005.

[6] A. Chaker \& G. Menguy, Efficacité interne d'un distillateur solaire sphérique, Rev. Energ. Ren. : Journées de Thermique, 2001, pp. 53-58 